\title{
Insurance and Subrogation: When the Pie Isn't Big Enough, Who Eats Last?
}

\author{
Jeffrey A. Greenblatt
}

Suppose $A$ is injured in an automobile accident, incurring $\$ 5,000$ of medical expenses. His automobile insurance carrier reimburses him for these expenses under a personal injury clause in his automobile insurance policy. The policy provides that the insurer's interest takes priority in any recovery from a tortfeasor. A then sues B, the tortfeasor, for these medical expenses, as well as an additional $\$ 10,000$ of pain and suffering.

When A recovers the full $\$ 15,000$ from $B$, nearly all courts agree that the doctrine of subrogation requires him to repay the $\$ 5,000$ of medical payments to his insurer. ${ }^{1}$ But when A recovers only $\$ 12,000$ from B, the outcome becomes less certain. Should A recover his $\$ 10,000$ of pain and suffering first, leaving $\$ 2,000$ for his insurer to recover its medical payments, or should the insurer receive its $\$ 5,000$ first, leaving $\$ 7,000$ for $\mathrm{A}$ ?

The amount of money at stake boggles the mind-and rivals the federal deficit. The issue of priority is not limited to automobile coverage or to a specific kind of injury; it may involve any first party insurance, including homeowner's, health, and disability. ${ }^{2}$ The tobacco litigation alone may well settle for $\$ 250-300$ billion dollars, ${ }^{3}$ and health care insurers will want their share.

One would think the matter settled by the contract between the insurer and insured. A typical contract provides as follows:

Subrogation. This Company may require from the insured an assignment of all right of recovery against any party for loss to the extent that payment therefor is made by this Company. ${ }^{4}$

$\dagger$ First Rabbinic Degree 1989, Telshe Rabbinical College; Second Rabbinic Degree 1993, Telshe Rabbinical College; J.D. 1997, The University of Chicago.

1 Mark S. Rhodes, 16 Couch Cyclopedia of Insurance Law \$ 61:29 at 109 (Law Co-op rev ed 1983) ("Couch on Insurance").

2 Insurance purchased by an individual to compensate him in the event of loss is referred to as first party insurance.

3 Alix M. Freeman and Suein L. Hwang, Peace Pipe: Philip Morris, RJR And Tobacco Plaintiffs Discuss a Settlement, Wall St J A1 (Apr 16, 1997).

4 Garrity v Rural Mutual Insurance Co, 77 Wis 2d 537, 253 NW2d 512, 513 (1977). See also Wimberly $v$ American Casualty Co of Reading, $\mathrm{Pa}, 584$ SW2d 200, 201 (Tenn 1979). Blue Cross and Blue Shield have a more explicit clause: 
The clause seems unambiguous on its face: when the insurer has made a payment, it may require the insured to assign his rights to recover that payment. Under the contract, the insurer recovers first. Nevertheless, many courts require that the insured be fully compensated before the insurer receives anything, ignoring the terms of the contract. ${ }^{5}$ They base their holdings on a variety of rationales: ambiguous or unclear language in the contract provision; risk allocation; and a talismanic doctrine that the insured must be "made whole," which some courts assert is an unalterable element of subrogation.

Subrogation is an equitable doctrine under which one who has paid a debt for which he is secondarily responsible takes over the creditor's rights and remedies against the party primarily responsible for that debt. ${ }^{6}$ In the insurance context, subrogation is the right of the insurer "to be put in the position of its insured against third parties legally responsible to its insured for the loss which the insurer has both insured and paid." Thus, the right of subrogation technically gives the insurer only the right to recover from the tortfeasor or other third parties, but not from its insured. ${ }^{8}$ Nevertheless, it has come to include the right of an insurer to recover its outlays, either from a tortfeasor or from an insured who has already collected from a tortfeasor. ${ }^{9}$

In the event any benefits or services of any kind are furnished to you or payment made or credit extended to or on behalf of any covered person for a physical condition or injury caused by a third party or for which a third party may be liable, the Plan shall be subrogated and shall succeed to such covered person's rights of recovery against any such third party to the full extent of the value of any such benefits or services furnished or payments made or credits extended.

Higginbotham v Arkansas Blue Cross and Blue Shield, 312 Ark 199, 849 SW2d 464, 465 (1993).

${ }_{5}$ Garrity, 253 NW2d at 516; Rimes $v$ State Farm Mutual Automobile Insurance Co, 106 Wis 2d 263, 271-72, 316 NW2d 348, 353 (1982) (following Garrity).

6 Ronald H. Horn, Subrogation in Insurance Theory and Practice 13-14 (S.S. Huebner Foundation 1964).

- Liberty Mutual Fire Insurance Co v Auto Spring Supply Co, 59 Cal App 3d 860, 864, 131 Cal Rptr 211 (1976), citing Sacramento-Yolo Port District $v$ Cargill of California, Inc, 4 Cal App 3d 1004, 1010, 84 Cal Rptr 822 (1970).

${ }^{8}$ Horn, Subrogation in Insurance at 13-14 (cited in note 6).

${ }^{9}$ See, for example, Florida Farm Bureau Insurance Co v Martin, 377 S2d 827, 828-29 (Fla Dist Ct App 1979).

For purposes of this Comment, it is irrelevant whether the insurer proceeds against the tortfeasor or against an insured who has already collected payment from the tortfeasor. The substantive rights among the parties do not change. See Automobile Insurance Co of Hartford $v$ Conlon, 153 Conn 415, 216 A2d 828, 829 (1966) ("The proposition is well established that an insurer's right to subrogation ... includes a claim against any judgment secured by the insured against any party at fault for the amount paid by the insurer in satisfaction of the insured's damage claim under the policy.") (citations omitted). 
The question of priorities has generated considerable confusion in the courts. Some courts require the insured to be fully compensated before the insurer recovers its outlays; others require the insurer to be compensated before the insured is paid (also called pro tanto); yet others require pro rata sharing. The only unanimity in the courts is a categorical rejection of insurerfirst as a default rule. Arguments on all sides of the debate are unpersuasive because they focus on whether subrogation as an historical doctrine permits the insurer to recover first, rather than focusing on the optimal contract term.

This Comment approaches the question from the standpoint that, while the historical doctrine is a useful starting place, it should neither be considered in a vacuum nor taken as a given. Particularly when insurance contracts are involved, the analysis should focus on the heart of insurance issues: risk allocation. This Comment argues that optimal risk allocation dictates that the insurer should recover first.

Section I introduces the law of subrogation-its history, current incarnation, and the policies that drive it. The Section ends with a description of the mechanics of subrogation as applied to the insurance context. Section II sets out the various approaches courts have taken when faced with questions of subrogation priority and the contractual terms affecting it. Section III contains an analysis of the law of subrogation. It begins with a doctrinal analysis, exploring how the law of suretyship would treat subrogation priority in the insurance context and explaining the differences between suretyship and insurance. Section III concludes with an economic analysis of insurance subrogation, including risk allocation, definitional problems, and the potential for strategic behavior.

\section{SUBRogation: A PRIMER}

Subrogation finds its roots in suretyship. Some commentators have suggested that suretyship derives from the Roman civil law doctrine of Cessio Actionum. ${ }^{10}$ Under this doctrine, A could

${ }^{10}$ Horn, Subrogation in Insurance at 15 (cited in note 6); M.L. Marasinghe, An Historical Introduction to the Doctrine of Subrogation: The Early History of the Doctrine, 10 Valp L Rev 45, 50 (1975). More likely, the origin is in Talmudic Law, where a surety who discharges the debt of a debtor may proceed directly against the debtor; his right arises by operation of law. Tractate Baba Basra 174(a), Babylonian Talmud (discussing a surety repaying a debt incurred by minor orphans' father). Maimonidies (11th century) cites the doctrine in his Code, adding that this rule only applies when the debtor asked the party to become a surety; that is, when A has a legal obligation to pay the creditor. Maimonidies Code, Laws of Debtor-Creditor 26:6. When the party pays the creditor of his own volition, he may not proceed against the debtor. Id. 
acquire B's rights against $\mathrm{C}$. There are, however, striking differences between the Roman law doctrine and its present-day analog. First, under Roman law, B had to expressly cede those rights to A; they did not arise by operation of law. Second, since the discharge of the debt terminated any claims $B$ could make against $\mathrm{C}$, if A did not acquire B's rights before or at the time he paid C's debt, he was forever barred from pursuing $\mathrm{C}$.

Whatever its venerable origins, subrogation is now firmly ensconced as a doctrine of equity. ${ }^{11}$ This equitable character has led many courts to adopt the "made-whole" doctrine, which holds that the insured must be fully compensated before the insurer can recover any of its outlays. ${ }^{12}$

In the patois of subrogation, the party to whom the debt is owed is the subrogor; the party who has paid him and succeeds to his rights is the subrogee. The subrogee is said to be subrogated to the rights of the subrogor. In the suretyship context, the creditor is the subrogor and the surety (guarantor) is the subrogee. As applied to insurance, the tortfeasor "owes a debt" to the insured victim. The insured victim may be thought of as the creditor, and his insurance company is thus secondarily liable to him for the tortfeasor's debt: if the tortfeasor does not pay the insured, the insurer must pay for the insured's injuries. Thus, the insured victim is the subrogor and the insurance company is the subrogee.

There are four essential elements of a subrogation claim: (1) the party claiming the subrogation rights has paid the debt; (2) it has paid the debt pursuant to a legal obligation, and not merely voluntarily; (3) it is secondarily liable for the debt; and (4) allowing the subrogation will not cause injustice to the subrogor. ${ }^{13}$

The doctrine of subrogation serves three functions. First, it prevents the subrogor (here, the insured victim) from being unjustly enriched by recovering once from his insurance company

"See, for example, Powell v Blue Cross and Blue Shield of Alabama, 581 S2d 772, 774 (Ala 1990) ("The entire law of subrogation . . . is based upon equitable principles."); Couch on Insurance $\S 61: 20$ at 96-97 (cited in note 1) ("The doctrine of subrogation in insurance ... has its origin in general principles of equity .... [S]ubrogation ... is purely equitable in its nature, and will not be enforced when it would work injustice to the rights of those having equal equities.") (citations omitted).

${ }^{12}$ See, for example, Rimes $v$ State Farm Mutual Automobile Insurance Co, 106 Wis $2 \mathrm{~d}$ 263,316 NW2d 348, 353 (1982) ("The entire law of subrogation is based upon equitable principles.... Thus, even though an insured has recovered from a tortfeasor a sum more than sufficient to equal the subrogated amount claimed by the insurer, the insurer is not entitled to subrogation unless the insured has been made whole for his loss."); Powell, 581 S2d at 777 (describing full compensation as "a prerequisite to the right of subrogation" that cannot be contracted away).

${ }^{13}$ John Alan Appleman, 11 Insurance Law and Practice $\$ 6501$ at 431 (West rev ed 1981). 
and once from the tortfeasor. Second, it reimburses the insurance company for its payments. Third, it places the burden of compensation on the tortfeasor and thus deters injurious behavior. ${ }^{14}$

Subrogation arises in the insurance context when an insurance company reimburses its insured for injuries he received at the hands of a tortfeasor. Technically, subrogation only permits the insurer to pursue the tortfeasor; an insurer has other rights that enable it to recover from an already compensated insured. ${ }^{15}$ Most courts, however, ignore this distinction..$^{16}$

Subrogation arises either by operation of law or by contract. Subrogation by operation of law, called legal or equitable subrogation, arises when, pursuant to an obligation, one party pays a debt owed to another by a third party. Subrogation by contract, also called conventional subrogation, arises in the insurance context when an insurance policy explicitly grants the insurer a right of subrogation. ${ }^{17}$ Insurance policies usually include such a provision.

\section{SUBROGATION PRIORITY}

Courts agree that under the common law an insurer's equitable subrogation interest does not arise until the insured has been made whole. ${ }^{18}$ Courts part company, however, when a contract gives the insurer's subrogation interest priority in any recovery from a tortfeasor. Courts differ on three points: first, whether to permit the contract to alter equitable subrogation rights at all; second, how to decide whether the insured has been made whole; and third, if a contract can give priority to the insurer, how explicitly it must do so.

\footnotetext{
1" Couch on Insurance $\$ 61: 18$ at 9 (cited in note 1).

${ }^{15}$ Liberty Mutual Fire Insurance Co v Auto Spring Supply Co, 59 Cal App 3d 860, 864, 131 Cal Rptr 211 (1976), citing Sacramento-Yolo Port District $v$ Cargill of California, Inc, 4 Cal App 3d 1004, 1010, 84 Cal Rptr 822 (1970) (defining insurer's subrogation right as one against "third parties" legally responsible for the insured's loss).

${ }^{16}$ See, for example, Florida Farm Bureau Insurance Co $v$ Martin, 377 S2d 827, 828-29 (Fla Dist Ct App 1979) (Insurer sought reimbursement under a subrogation claim from funds recovered from the tortfeasor by the insured.). But see Maynard v State Farm $\mathrm{Mu}$ tual Automobile Insurance Co, 902 P2d 1328, 1333 (Alaska 1995) (distinguishing right of reimbursement, in the form of a setoff in an insurance policy, from subrogation).

${ }^{17}$ Robert E. Keeton and Alan I. Widiss, Insurance Law $\$ 3.10$ at 220 (West 1988).

${ }^{28}$ See, for example, Higginbotham v Arkansas Blue Cross and Blue Shield, 312 Ark 199, 849 SW2d 464, 466 (1996).
} 
A. Contractual Alteration of Common Law Subrogation

1. Giving priority to the insured: the "made-whole" doctrine.

In Rimes $v$ State Farm Mutual Automobile Insurance Co, ${ }^{19}$ the Wisconsin Supreme Court held that, under both legal and conventional subrogation, the insured must be made whole before the insurer can share in the recovery. The court gave two reasons. First, the purpose of subrogation is to prevent double recovery by the insured, and such double recovery is impossible unless the insured has recovered the full amount of his damages from the tortfeasor. ${ }^{20}$ Second, the court reasoned that, "where either the insurer or the insured must to some extent go unpaid, the loss should be borne by the insurer for that is a risk the insured has paid it to assume."21 An extension of this argument is that insurance companies do not consider subrogation in setting their actuarial rates because of the difficulty of determining the mathematical probability of such recovery. ${ }^{22}$

Other courts have grounded the made-whole doctrine in suretyship subrogation. In Garrity $v$ Rural Mutual Insurance $\mathrm{Co}^{23}$ the court held that subrogation in insurance follows the law of suretyship. The law of suretyship in turn dictates that a surety, or guarantor, may not recover from the debtor until the creditor has been made whole. To clarify the relationships, consider the following example: Creditor loans $\$ 100$ to Debtor; Surety guarantees $\$ 25$ of the loan, so that if Debtor defaults, Creditor may look to Surety for payment of $\$ 25$. Debtor pays Creditor $\$ 50$ and then defaults. Creditor approaches Surety, who, pursuant to its obligation, pays Creditor \$25. At this point, Debtor owes Creditor and Surety $\$ 25$ each. The made-whole doctrine requires that Creditor be repaid the remaining $\$ 25$ owed to him before Surety can proceed against Debtor. The parallel to the insurance scenario is clear: the insurer may not recover from a tortfeasor until the insured has been made whole. ${ }^{24}$

19106 Wis $2 d$ 263, 316 NW2d 348, 353 (1982).

20 Id.

${ }^{21}$ Id at 355, quoting Garrity v Rural Mutual Insurance Co, 77 Wis 2d 537, 253 NW2d 512, 514 (1977).

${ }_{22}$ See Maynard v State Farm Mutual Automobile Insurance Co, 902 P2d 1328, 133334 (Alaska 1995) (but permitting recovery because State Farm proceeded under a reimbursement provision that expressly precluded double recovery by the insured); Rimes, 316 NW2d at 355.

23 77 Wis $2 d 537,253$ NW2d 512 (1977).

${ }^{24}$ See id at 514 ("[T]here is no subrogation until the insured has been made whole."). 
2. Priority to the insurer: the pro tanto approach.

At the opposite end of the spectrum are cases that permit the insurer to recover before the insured has been made whole. In Gibson $v$ Country Mutual Insurance $\mathrm{Co}^{25}$ the subrogation clause provided that the insurer would be subrogated to any recovery from a third party to the extent of its payments. ${ }^{26}$ The court found no violation of public policy in allowing subrogation, even though the insured had not been made whole. The court reasoned that subrogation would not deprive the insured of benefits paid for, since she only paid for coverages stated in the policy. ${ }^{27}$ Some courts have stated the proposition more forcefully:

In this case, [the insurer's] policy did not agree to indemnify [the plaintiff] for pain and suffering or disability. Yet, denial of its [subrogation] claim ... because [the plaintiff] had not also recovered for other elements of damage would have the effect of making [the insurer] an insurer against those losses as well. This would be a windfall to an insured who has not paid for such protection. ${ }^{28}$

\section{The pro rata approach.}

Florida once took a middle road. A Florida statute required a pro rata splitting of the recovery from a tortfeasor. ${ }^{29}$ Each party recovered an amount in proportion to the percentage of the total loss it bore minus its pro rata share of the costs incurred in recovering from the tortfeasor. ${ }^{30}$ Thus, when the insured has $\$ 10,000$ of pain and suffering and the insurer has paid $\$ 5,000$ of medical expenses, the insured would take $2 / 3$ of any recovery and the insurer would take $1 / 3{ }^{31}$

B. When Has the Insured Been Made Whole?

A state following the made-whole doctrine faces an immediate question: when has the insured been made whole? Courts have given two different answers to this question. The Rimes

${ }^{25} 193$ Ill App 3d 87, 549 NE2d 23 (1990).

${ }^{25}$ Id at 24.

${ }^{27}$ Id at 26.

${ }^{28}$ Ludwig v Farm Bureau Mutual Insurance Co, 393 NW2d 143, 147 (Iowa 1986).

${ }^{2}$ Fla Stat Ann $\$ 768.76(4)$ (West 1986 \& Supp 1996). This section discusses Florida Law prior to 1993. In 1993, Florida changed to an "insurer first" position.

${ }^{30} \mathrm{Id}$.

${ }^{31}$ This Comment presents a simplified application of the Florida pro rata statute by ignoring the costs of recovering from the tortfeasor. For a fuller description of the statute's intricacies, see generally Magsipoc v Larsen, 639 S2d 1038 (Fla Dist Ct App 1994). 
court held that the insured has been made whole only when he has been compensated for all the elements of damage, not merely those damages for which the insurer has indemnified him. ${ }^{32}$ The court also held that allocation of damages to medical expenses would be irrelevant, since a cause of action against a tortfeasor is indivisible. ${ }^{33}$

On the other hand, in Ludwig $v$ Farm Bureau Mutual Insurance $\mathrm{Co}_{,}^{34}$ the Iowa Supreme Court held that the separate elements of a damage award can be identified and credited to the subrogated claims, even if the insured has not been made whole with regard to his other claims. The court reasoned that the made-whole approach of Rimes would effectively make Farm Bureau an insurer against elements of a claim, here pain and suffering, for which the insured had not paid..$^{35}$

Courts confronting this issue often conduct a mini-trial to determine whether the insured has been made whole. The Ludwig court suggested that, if the settlement or judgment were undifferentiated, the amount attributed to the subrogation might have to be determined by a mini-trial. ${ }^{36}$ Similarly, the Rimes court concluded that the trial court had acted appropriately in conducting a mini-trial on whether the insured had been made whole. $^{37}$

\section{Explicitness of the Subrogation Priority}

Though insurance contracts almost always contain terms giving priority to the insurer, courts do not agree on how explicit those terms must be. Most courts have held that a clause providing that the insurer "shall be subrogated ... to the full extent of the value of ... [its] payments," explicitly gives first priority to the insurer. ${ }^{38}$ But at least one court has held that similar language was not sufficiently explicit. ${ }^{39}$ And at least one court has invoked the made-whole doctrine despite a clause expressly de-

\footnotetext{
32316 NW2d at 355.

${ }^{33}$ Id.

34 393 NW2d 143, 146 (Iowa 1986).

${ }^{35}$ Id at 147.

${ }^{35}$ Id at $146 \mathrm{n} 2$.

${ }^{37} 316$ NW2d at 356 (in context of settlement).

${ }^{38}$ See, for example, Higginbotham v Arkansas Blue Cross and Blue Shield, 312 Ark 199, 849 SW2d 464, 465-66 (1993).

${ }^{39}$ Thiringer $v$ American Motors Insurance Co, 91 Wash 2d 215, 588 P2d 191, 192, 194 (1978) (finding nothing in the language of insurance policy that altered common law made-whole doctrine).
} 
signed to circumvent subrogation and its made-whole limitations. ${ }^{40}$

\section{DOCTRINAL AND ECONOMIC JUSTIFICATIONS}

\section{A. The Suretyship Model}

Many courts believe that the made-whole requirement is inherent to subrogation. The argument, usually presented with syllogistic certainty, runs as follows: In the law of suretyship, the creditor must be made whole before a surety may pursue a subrogation claim. Insurance subrogation is based on suretyship subrogation. Therefore, insurance subrogation requires that the victim, the analog of the creditor, be made whole before the insurer may pursue its subrogation claim. ${ }^{41}$ This Section argues that the made-whole requirement is inappropriate to the insurance context. Part A shows that the doctrinal argument itself is mistaken. Part B directs the inquiry to its proper place-risk allocation. Finally, Part $\mathbf{C}$ discusses the messy difficulties of applying the made-whole doctrine.

\section{Litigated claims.}

As with insurance, subrogation in suretyship involves a three party transaction. A debtor (D) borrows money from a creditor (C). As an inducement to $\mathrm{C}$ to make the loan, a guarantor, or surety (S), guarantees the debtor's repayment of the loan: if $\mathrm{D}$ defaults, $\mathrm{C}$ may look to $\mathrm{S}$ for payment. The debtor is called the primary obligor, the creditor is called the obligee, and the surety is called the secondary obligor.

We begin with a simple case of suretyship, one that does not implicate the made-whole doctrine. Assume that C lends D $\$ 15,000$, with $S$ acting as surety for the entire amount of the loan. D defaults, and $C$ recovers the full $\$ 15,000$ from $S$. Under suretyship law, $D$ has the primary duty to bear the cost of performance. S may enforce this duty by recourse to one of four mechanisms: enforcement of D's duty of performance, also known as exoneration or quia timet relief; reimbursement; restitution; or

${ }^{\circ}$ Powell v Blue Cross and Blue Shield of Alabama, 581 S2d 772, 774, 777 (Ala 1990) (applying made-whole doctrine notwithstanding policy providing that "[s]eparate from and in addition to the Administrator's right of subrogation ... [t] the right to reimbursement of the Administrator comes first even if a Member is not paid for all of his claim for damages.").

"1 See text accompanying note 23. 
subrogation..$^{42}$ Here we are interested in reimbursement and subrogation.

Conceptually, reimbursement and subrogation differ with respect to whose rights the surety seeks to enforce when proceeding against the defaulting debtor. When the surety proceeds under a right of reimbursement, he seeks to enforce his own rights. When the surety proceeds under subrogation, he seeks to enforce the creditor's rights. ${ }^{43}$

In most cases the distinction makes no difference-the surety can recover as well under subrogation as she can under reimbursement. ${ }^{44}$ Nevertheless, the Restatement (Third) of Suretyship and Guaranty notes several situations in which the conceptual distinction creates practical differences.

First, when a surety proceeds under subrogation, he is subject to whatever defenses the principal obligor has against the obligee; under reimbursement he is subject only to those defenses of which he had notice. ${ }^{45}$ Second, under subrogation, the surety is subject to the statute of limitations on the creditor's claim; under reimbursement, he is subject only to the independent statute of limitations on his own claim, which will typically not have run until after the statute of limitations has run on the creditor's claim. ${ }^{46}$ Third, whereas the surety is not entitled to subrogation until the creditor has been made whole, the right of reimbursement contains no such requirement. In other words, the madewhole doctrine does not apply to the right of reimbursement. The surety "has a right of reimbursement even if its performance of the secondary obligation is only partial or if the underlying obligation is otherwise not totally discharged by [its] performance. ${ }^{\$ 77}$ Finally, under subrogation, the surety succeeds to the priority

12 Restatement (Third) of Suretyship and Guaranty $\S 18$ at 81 (1996).

${ }^{4}$ Id $\S 28$, comment $c$ at 121 .

"Id.

4 Id at 121-22. See also $\S 24$.

${ }^{45}$ Assume that on January 1, Debtor borrows $\$ 1,000$ from Creditor; Surety guarantees the loan. On February 1, Debtor defaults, and on September 1, Surety pays Creditor. If Surety proceeds under subrogation, he is enforcing Creditor's cause of action, which arose at the time of the breach, on February 1. If, on the other hand, Surety proceeds under the right of reimbursement, he is bringing his own cause of action, which arises on September 1, when he pays Creditor. The statute of limitations on the reimbursement claim in this hypothetical thus expires seven months later than the subrogation claim. See id at $\$ 28$, comment $c$ at 122 . This may turn out to be the most important reason for resolving subrogation priorities. While an insurer will usually be able to circumvent the made-whole doctrine by resorting to reimbursement rather than subrogation, this option is foreclosed when the statute of limitations has run on its own claim, as may be the case in the tobacco litigation. See text accompanying note 3.

${ }^{17}$ Restatement (Third) of Suretyship and Guaranty $\S 28$, comment $c$ at 122.

${ }^{48}$ Id. 
and secured status of the creditor. Under reimbursement, on the other hand, the priority of the surety's claim dates from the time that the debtor's obligation transfers to him. Furthermore, his claim does not take on whatever secured status the creditor may have had. ${ }^{48}$

Now, consider two patterns of suretyship that do implicate the made-whole doctrine. In what we will call the solvent debtor pattern, assume that $\mathrm{C}$ lends $\mathrm{D} \$ 15,000$, with $\mathrm{S}$ acting as surety for $\$ 5,000$. D defaults, and $C$ recovers the $\$ 5,000$ guaranteed by S. Naturally, C proceeds against D for the remaining $\$ 10,000$, and $S$ proceeds against $D$ for the $\$ 5,000$ on which he was only secondarily liable. So far, this scenario precisely parallels the original tale of the tortfeasor, the victim, and insurer.$^{49} \mathrm{~S}$ must decide whether to proceed under reimbursement or under subrogation. Assuming that $\mathrm{D}$ is solvent, $\mathrm{S}$ has no reason to proceed under subrogation, and every reason not to. Under reimbursement, S may recover his $\$ 5,000$ from $\mathrm{D}$, without regard to whether $\mathbf{C}$ has been made whole. Under subrogation, however, $\mathbf{S}$ cannot recover his $\$ 5,000$ until $\mathrm{C}$ has recovered his $\$ 10,000 .^{50}$

But now assume that $D$ is not solvent. In what we will call the insolvent debtor pattern, $C$ again loans $\$ 15,000$ to $D$, this time taking a perfected security interest in D's manufacturing equipment, which is worth $\$ 12,000$. D has additional property worth $\$ 3,000$. As an inducement to $\mathrm{C}$ to loan the funds, $\mathrm{S}$ guarantees $\$ 5,000$ of the loan. ${ }^{51}$ Assume further that $\mathrm{D}$ has two other unsecured creditors to whom he owes $\$ 3,000$ each. D defaults and files for bankruptcy. The question is the same as that posed at the beginning of this Comment: as between $\mathrm{S}$ and $\mathrm{C}$, who gets priority?

This pattern plays out very differently than the previous one. C will successfully exercise his $\$ 12,000$ security interest in the manufacturing equipment, and will recover the remaining $\$ 3,000$ from $S$, pursuant to the suretyship agreement. $S$ will then want to recover his $\$ 3,000$ from $D$. If $S$ proceeds under his right of reimbursement, his claim will be unsecured, and he will share equally in the remaining $\$ 3,000$ with the other unsecured credi-

\footnotetext{
4 See introduction to this Comment.

${ }^{50}$ Some courts embrace the made-whole doctrine because they find the idea of the insured and surety competing for the tortfeasor's funds to be repugnant. See, for example, Garrity, 253 NW2d at 514. See also Restatement of Suretyship \$ 27, comment b at 11314. But there appears to be no such repugnancy in suretyship when the surety proceeds against the debtor under his right of reimbursement while simultaneously the creditor sues on the primary obligation.

51 While the loan is over-collateralized, this may be due to risks in the fluctuating value of the collateral.
} 
tors, recovering only $\$ 1,000 .^{52}$ If there were no made-whole requirement for subrogation, $\mathrm{S}$ would choose to proceed under subrogation instead of reimbursement, since by doing so he would acquire a secured status identical to C's and share in the proceeds of the manufacturing equipment. ${ }^{53}$

This scenario explains why a surety may not claim subrogation until the creditor has been made whole. ${ }^{54}$ Subrogation permits the surety to "step into the shoes" of the creditor. Here, this would mean that $S$ is not relegated to sharing equally with the other unsecured creditors; instead he competes with $\mathrm{C}$ for the manufacturing equipment. And, following the rules of subrogation, S's interest in the secured asset would be equal to C's in every respect. ${ }^{55} \mathrm{~S}$ and $\mathrm{C}$ would therefore share pro rata in the collateral, ${ }^{56}$ with $\mathrm{C}$ receiving $\$ 9,600$ and S receiving $\$ 2,400 .{ }^{57}$

Such a result was specifically not intended by the parties, and the doctrine of subrogation properly precludes it. To see why, we must unpack the transaction. The parties intended that if $\mathrm{D}$ should default, $\mathrm{C}$ would lose nothing, recovering $\$ 12,000$ from his security interest and up to $\$ 5,000$ from S. S's guaranty was to be an inducement to $C$ to loan $D$ the funds. Presumably, if $S$ had not agreed to act as a surety, $\mathrm{C}$ would either not have agreed to the loan, or would have demanded a higher interest rate, compensating for the riskier nature that the loan now assumed. S, on the other hand, agreed to assume the risk that, in the event that D were to default, C's security interest in the collateral would not be sufficient to cover D's outstanding debt to C. S agreed to make

${ }^{52}$ See UCC $\$$ 9-301, 9-302, 9-312 (ALI 1996).

${ }^{53}$ See Restatement of Suretyship $\S 28(1)(c)$ and comment e at 123-24.

${ }^{5}$ Id $\S 27$ at 113-14 (reporting that a surety may not proceed under subrogation until the underlying obligation to the obligee has been fully satisfied).

${ }^{55}$ See id $\S 28(1)$ ("To the extent that the secondary obligor is subrogated to the rights of the obligee, the secondary obligor may enforce, for its benefit, the rights of the obligee."). See also id $\$ 29$ ("Except as provided by statute, when a secondary obligor is subrogated to rights of the obligee, the secondary obligor has the same priority with respect to those rights as the obligee.").

${ }^{56}$ Article 9 of the Uniform Commercial Code does not seem to cover this precise scenario. See generally § 9-312, and particularly § 9-312(5): "In all cases not governed by other rules ... priority between conflicting security interests in the same collateral shall be determined according to the following rules: (a) Conflicting security interests rank according to priority in time of filing or perfection." Here the priorities would date from the same time, so § 9-312 is of no help. That § 9-312 does not address this situation makes sense, since this sort of equal priority in the same collateral is exactly what Article 9 was designed to prevent.

${ }^{57} \mathrm{~S}$ and $\mathrm{C}$ would share pro rata in the collateral, along the same lines as UCC § 9315(2). Here, $C$ loaned $D \$ 15,000$ and recovered $\$ 3,000$ from $S$, for a net loss of $\$ 12,000$; $S$ is out $\$ 3,000$. They would then share in the collateral in the same proportion that their losses bear to the total loss: $12 / 15=4 / 5$, and $3 / 15=1 / 5$, so $C$ would receive $\$ 9,600(4 / 5 *$ $12)$ and $S$ would receive $\$ 2,400(1 / 5 * 12,000)$. 
up the shortfall precisely so that $\mathrm{C}$ would not have to compete with the other unsecured creditors. S may have been able to take steps to protect himself: under the facts of this scenario, he could have taken a security interest in D's remaining assets. And even if he could not have protected himself, he agreed to the terms of his suretyship. Perhaps S was compensated for his guaranty; perhaps he merely offered his guaranty as a friend to D. Either way, the intentions of the parties at the outset of the transaction were abundantly clear.

The made-whole doctrine gives effect to these intentions. Without the made-whole requirement, $\mathrm{S}$ and $\mathrm{C}$ would share the risk of D's insolvency, depriving $\mathrm{C}$ of the benefit of his security interest. That would thwart the parties' intent, twisting it beyond recognition. To avoid this result, the law of suretyship requires that a surety seeking to recover under subrogation wait until the obligee for whom he is a surety has been made whole. ${ }^{58}$ $C$ will receive his $\$ 12,000$ from the security interest, and S must proceed under his right of reimbursement and take his chances with the other unsecured creditors, as the parties originally intended.

Returning to insurance subrogation, we now ask whether the solvent debtor pattern or the insolvent debtor pattern best fits the scenario in which the insured victim recovers less than his full damages from the tortfeasor. Asked another way, how well does the doctrine of subrogation, which originated in suretyship, translate to tort insurance?

At first blush, the dynamics in suretyship and insurance are simply too different for us to apply the former to the latter. In suretyship, all three parties entered into a consensual agreement, their intentions clear to one another and a court sitting in judgment. In tort insurance, on the other hand, the primary obligor-the tortfeasor-is not a party to the agreement at all; the only agreement is a contract between the insured and the insurer, and the tort giving rise to the dispute is not consensual at all.

But this difference is chimerical. In suretyship, the only agreement that makes a difference is the one that exists between the secondary obligor-the surety-and the obligee-the creditor. The debtor makes only a passive, background contribution to the dynamic: it is the debtor's borrowing that gives rise to the suretyship, and in the event of default it is his assets that will be looked to for ultimate satisfaction of at least part of the debt. For

${ }^{58}$ See Restatement of Suretyship $\$ 27$ and comment b at 113-14. 
purposes of subrogation, however, the debtor himself is not important to the transaction. The surety and the creditor-the secondary obligor and the obligee-are the players here, and the game is one of risk allocation: who bears how much of the risk that the debtor will default?

The insurance context presents a similar scenario. The insured plays the part of the creditor or obligee, the victim to whom the tortfeasor will owe the debt. The insurer is the secondary obligor, the entity that will pay the "creditor" if the primary obligor does not. And, of course, the tortfeasor plays the part of the primary obligor or debtor. Here, as in suretyship, the obligee (insured) and the secondary obligor (insurer) will agree to a risk allocation without the participation of the primary obligor.

But instead of looking for differences between suretyship and tort insurance, consider for a moment their similarities. Both involve three parties, both involve consensual risk allocation, and both involve a creditor who has not been made whole by his debtor. If they are similar, why not treat them similarly? In tort insurance, as in suretyship, the insurer may proceed against the primary obligor either by subrogation, or by right of reimbursement. Recall that while subrogation requires that the subrogor be made whole before the subrogee can step into his shoes, the right of reimbursement carries no such requirement. If we are true to the suretyship model, the insurer has a right to be reimbursed by the tortfeasor, regardless of whether the insured has been made whole. Only if the insurer proceeds under subrogation should the made-whole doctrine limit recovery.

When the insured has not been made whole, the insurer will proceed under its right of reimbursement if it possibly can. The question then becomes whether some factor precludes the insurer from proceeding under a right of reimbursement, as it did in the insolvent debtor pattern. ${ }^{59}$ Or, to return to the question as originally framed: is tort insurance more like the first or second patterns discussed in suretyship? ${ }^{60}$

The insurance scenario has much in common with the insolvent debtor pattern of suretyship. In both cases, the obligee has not been made whole. In both cases, ignoring the made-whole doctrine means that the secondary obligor, who is enforcing a right of the obligee, may compete with the obligee for the debtor's assets. It seems as odd in insurance as it does in suretyship that

\footnotetext{
69 See text accompanying notes 51-52.

${ }^{60}$ See the first pattern at text accompanying notes $49-50$, and the second pattern at text accompanying notes 51-52.
} 
a secondary obligor could enforce the obligee's rights to the detriment of that same obligee. In both contexts, the law conceives of the obligee telling the secondary obligor, "You may succeed to my rights against the debtor, but not if it means hurting me in the process." The opposite scenario conjures up the image of shooting a man with his own gun.

Imagery aside, when considered together, reimbursement and subrogation in the suretyship context serve to allocate the risks of insolvency, that is, who takes his chances with the unsecured creditors. The examples in the comments to Sections 27 and 28 of the Restatement (Third) of Suretyship and Guaranty deal with insolvency and security interests. ${ }^{61}$ When there is no insolvency or security interest, the surety does not need to stand in the creditor's shoes, may proceed under reimbursement, and may recover from the debtor even if the creditor has not recovered in full. When the debtor is insolvent, however, the surety will need the benefit of the creditor's security interest. The surety will therefore prefer to proceed under subrogation and so will need to wait until the creditor has been made whole.

In contrast to suretyship, the issue in insurance has nothing to do with security interests. If the insured has not been made whole because of an inadequate jury verdict, the issue is not who takes his chances along with the unsecured creditors. That issue is resolved. No one does. Even if the tortfeasor has assets not subject to a security interest, the creditor could not reach them. If, on the other hand, the insured has not been made whole because the tortfeasor is insolvent and has insufficient insurance, the insurer is no better off seeking recovery under subrogation than it is under reimbursement, unless, of course, the insured victim had the foresight to take a security interest in the tortfeasor's property before the accident. ${ }^{62}$

Under the suretyship model, the surety/subrogee is never limited to either reimbursement or subrogation; it may always choose one or the other, and will do so depending on the advantages of the different causes of action. In the insurance context, therefore, when the tortfeasor is solvent and the insurer does not need to resort to subrogation, the insurer should not be limited to recovery subject to the limitations of subrogation. Rather, the insurer should be entitled to proceed under reimbursement, and therefore without regard to whether the insured has been made

\footnotetext{
${ }^{61}$ See Restatement of Suretyship $\S 27$, comment b, illustration 4 at 155 and $\S 28$, comment e at 123-24.

${ }^{62}$ A tort victim is not automatically considered a secured creditor. See UCC $\$ \$ 9-$ 301(3), 9-312, 9-104.
} 
whole. Even if the tortfeasor is insolvent, the insurer gains nothing by proceeding under subrogation: the victim is not likely to have a security interest in the tortfeasor's assets. By extension, the insurer should also be able to recover its outlays from an insured who has recovered from the tortfeasor.

\section{Settlement.}

So far we have adhered rather closely to the suretyship model. In the litigated claims discussed above, the model is relatively simple and translates cleanly to the insurance context. But when the tortfeasor and the insured settle their claims without a verdict, the analysis becomes more complex.

Assume that $C$ loans $\$ 15,000$ to $D$, and, as an incentive to $C$ to make the loan, $S$ acts as surety for $\$ 5,000$ of the loan. D defaults and $C$ recovers $\$ 5,000$ from $S . D$ and $C$ enter into a settlement agreement wherein $C$ agrees to release D's obligation in exchange for $\$ 7,000$.

Under the Restatement (Third) of Suretyship and Guaranty, $D$ is discharged from his obligations to $S$, unless the terms of the release provide otherwise. ${ }^{63}$ If the terms of the settlement allow S's rights to continue against $D, S$ may recover from $D$ under reimbursement or subrogation, just as it would have had $\mathbf{C}$ not released $D^{64}$

If, however, $\mathrm{C}$ releases $\mathrm{D}$ and does not provide that $\mathrm{S}$ 's rights continue against $D$, then $S$ may not recover from $D .{ }^{65}$ When $S$ has already paid C, S's rights of reimbursement and subrogation against $\mathrm{D}$ are destroyed, and $\mathrm{S}$ would suffer a loss. While contract law recognizes a third party beneficiary, nowhere does it recognize a third party "maleficiary": although two parties may enter into a binding agreement that one will pay money to a third party, they may not bind a third party to pay one of them, absent his consent. Similarly, in suretyship, if $\mathrm{C}$ and D can agree that $\mathbf{S}$ may not recover his losses, they are making $\mathbf{S}$ a third party maleficiary. Suretyship countenances this no more than contract law does: when an obligee impairs the surety's right of reimbursement or subrogation, the surety has a claim against the obligee. ${ }^{66}$

\footnotetext{
${ }^{63}$ Restatement of Suretyship \$ 39(a). Section 38(1) provides that the release effects a "preservation of the secondary obligor's recourse" only if the release explicitly provides that $\mathbf{C}$ retains the right to recover from $\mathbf{S}$ and that $\mathbf{S}$ 's rights against $D$ continue as though the release had not been granted.

${ }^{64}$ Id $\S 38(2)$.

6 Id $\S 39(a)$.

${ }^{*}$ Id $\S 37(3)$-(4). This result is reached through the interaction of two sections of the
} 
The tort insurance analog parallels this fact pattern. Tortfeasor injures Insured, who sustains $\$ 15,000$ of damages, $\$ 5,000$ of which are damages covered by Insurer. Insurer pays Insured the $\$ 5,000$. Insured and Tortfeasor then enter into a settlement agreement under which Insured agrees to release Tortfeasor in exchange for $\$ 7,000$. Under a strict application of suretyship law, Insurer would no longer be able to recover his $\$ 5,000$ from Tortfeasor, and so is impaired to that extent. Insurer should therefore have a cause of action against Insured for the $\$ 5,000$.

This result is intuitively attractive: there is no reason that a tortfeasor and his victim should be able to reach an agreement that harms the insurer. If this were not the rule, tortfeasor and the victim could choose to settle, avoiding the uncertainty of a trial at the expense of the insurer. Oddly, courts have applied the made-whole doctrine in the tort settlement context, essentially allowing insureds to exchange their insurers' rights of recovery against tortfeasors for low transaction cost settlements. ${ }^{67}$

\section{Freedom of contract.}

Under suretyship law, the rights among the parties may be varied by contract. As the Restatement reports, "Each rule in this Restatement stating the effect of suretyship status may be varied by contract between the parties subject to it."

The only limitations that the Restatement places on such agreements are those imposed by contract law, such as good faith and unconscionability. ${ }^{69}$ The reporter's note states that "[t]he existence of the parties' power to order their relationship is usually assumed. Litigation in this area typically relates to the terms of the parties' agreement rather than to their power to agree."70

\footnotetext{
Restatement. Section 39(d) provides that to the extent that the obligee releases the debtor from the obligation, the surety has a claim against the obligee to the extent provided in Section 37(4). Section 37(4) provides that if the obligee "impairs the [surety's] suretyship status" after the surety performs any part of this suretyship obligation, the surety has a claim against the obligee to the extent that such impairment would have discharged the [surety]. Section 37(1) defines impairment as, inter alia, decreasing the surety's potential ability to cause the debtor to bear the cost of performance. Thus, had the creditor not released the debtor from the $\$ 15,000$ obligation, the debtor would have had to repay the full amount of the loan, and the surety would not have had to pay the $\$ 5,000$. The surety therefore has a $\$ 5,000$ claim against the creditor. See also id $\$ 37$, comment d, illustration 1 at 161.

${ }^{6}$ These courts have required a mini-trial to determine whether the insured has been made whole. See text accompanying notes 36-37.

${ }^{68}$ Restatement of Suretyship $\S 6$.

${ }^{69}$ Id $\S 6$, comment b at 29.

${ }^{20}$ Id $\S 6$, reporter's note at 30 .
} 
There is thus nothing within suretyship subrogation that precludes contracting around the made-whole doctrine.

In summary, there is no purely doctrinal justification for invoking the made-whole doctrine every time an insurer seeks to recover its outlays. Rather, the made-whole doctrine properly applies only when the insurer proceeds under subrogation proper, when it seeks to enforce its insured's rights against the tortfeasor.

\section{B. Risk Allocation}

The previous section showed that a purely doctrinal justification for the made-whole doctrine is unwarranted. This section returns to the more basic economic considerations. Deciding what law should apply without understanding the economics of insurance is the equivalent of determining chess moves by rolling dice. We therefore turn now to risk allocation, which lies at the heart of the priority issue. It is the party that recovers last that bears the risk of an incomplete recovery from the tortfeasor.

Along these lines, several courts have approached the priority issue from the perspective of giving the parties the benefit of their bargain. Courts adopting the made-whole doctrine assert that the insurer should bear the loss of an incomplete recovery because "that is a risk the insured has paid it to assume." Some courts have gone even further in asserting that insurance companies do not include subrogation in their actuarial computations because the probability is too difficult to calculate. ${ }^{72}$

On the other side of the debate, courts adopting a pro tanto rule assert that an insured has received the benefit of his bargain. For example, the Appellate Court of Illinois in Gibson $v$ Country Mutual Insurance Co asserted that the insured "paid for the coverages stated in the policy, subject to the conditions stated in the policy." ${ }^{33}$

Ironically, both approaches misapprehend the essential workings of insurance and actuarial rate setting. Insurance companies can take subrogation into account in setting their rates, at least in setting health insurance rates. ${ }^{74}$ There is no reason to as-

\footnotetext{
${ }^{71}$ Powell $v$ Blue Cross and Blue Shield of Alabama, 581 S2d 772, 776 (Ala 1990) (citations and internal quotation marks omitted).

${ }^{72}$ See generally Allstate Insurance Co v Druke, 118 Ariz 301, 576 P2d 489, 492 (1978); DeCespedes v Prudence Mutual Casualty Co of Chicago, IIl, 193 S2d 224, 227-28 (Fla Dist Ct App 1966); Cooper v Argonaut Insurance Companies, 556 P2d 525, 527 (Alaska 1976).

${ }^{73} 193$ Ill App 3d 87, 549 NE2d 23, 26 (1990).

${ }^{74}$ Harry L. Sutton, Jr. and Allen J. Sorbo, Actuarial Issues in the Fee-ForService/Prepaid Medical Group 46 (Center for Research in Ambulatory Healthcare
} 
sume that any other area of insurance is any different. But this is incidental. An insurance company sets its rates based on historical net costs. ${ }^{75}$ Thus, if the insurer had one hundred policyholders in the experience period, and experienced a total of $\$ 20,000$ in claim costs, it will set its actuarial premiums at $\$ 200$ per policy holder. ${ }^{76}$ If, on the other hand, the insurance company experienced $\$ 20,000$ in claim costs and received $\$ 5,000$ in subrogation, it will set its actuarial premiums at $\$ 150$ per policy holder. Thus, whether the insurer lists subrogation as a factor in its actuarial calculations is irrelevant; it is implicitly included.

This analysis suggests that the term included in the contract does not determine whether the insured is paying the insurer to assume the risk of an incomplete recovery. If the insured lives in a jurisdiction that has adopted the pro tanto rule, then he is paying a lower premium, reflecting the insurer's subrogation recovery. If, on the other hand, the insured lives in a jurisdiction that has adopted the made-whole doctrine, then he is paying a higher premium, reflecting the insurer's diminished subrogation recovery. ${ }^{77}$

This does not mean that a jurisdiction should never change its status quo because doing so would grant a windfall to one party or the other. Dislocation is incident to any change in a legal rule, and may be justified in the long run despite temporary inequities. Adherence to the status quo is particularly unjustified in the insurance context because, once the actuaries know that the legal rule has changed, they can project the changes in costs from subrogation recovery. ${ }^{78}$

It should therefore be clear that insurance companies are utterly indifferent as to which rule is adopted, since they can always spread their risks among their policyholders. Whether a court adopts a pro tanto regime or a made-whole regime, the insurance company will take care of itself. Courts should therefore

Admin 2d ed 1993) ("An adjustment to estimated total HMO expenses . . . should be included to project the impact of coordination of benefits, workers' compensation, and subrogation.") (emphasis added). See also Letter from Dean K. Lamb, Senior Actuary for Allstate Insurance Company, to Jeffrey A. Greenblatt, Jan 30, 1997 ("Lamb letter") (on file with U Chi L Rev).

${ }^{75}$ Telephone interview with Dean K. Lamb, Senior Actuary for Allstate Insurance Company, Jan 27, 1997. See also Lamb letter.

${ }^{76}$ This assumes what are termed actuarially fair rates, which means that the insurance company does not allow for profit and administration expenses in this model.

$\pi$ Under a pro rata regime, the result falls somewhere in between. While pro rata sharing does reimburse the insurer for outlays, it does not do so fully, driving premiums higher than in a pro tanto regime but not so high as in a made-whole regime.

${ }^{73}$ See Lamb letter (cited in note 74). 
not focus on contract terms or on whether the insured is actually paying for subrogation priority, but on risk allocation.

Yet analyzing risk allocation is particularly problematic in this context, for two normal presumptions of risk allocation appear to conflict. In risk allocation, we begin with the presumption that when one party is risk-averse ${ }^{79}$ and the other is riskneutral ${ }^{80}$ the risk-neutral party is the better risk bearer, and the parties should allocate the risk to him. This is particularly easy to see in the insurance context. An insurance company is paradigmatically risk-neutral because its very business is the spreading of risk. The insured, on the other hand, is paradigmatically risk-averse: otherwise he would not purchase insurance. Because a risk-averse individual is willing to pay more than the expected value of the loss to avoid it, both parties are better off allocating the risk to the insurance company. ${ }^{81}$ Given this presumption, we would expect to see the parties agree to allocate the risk of an incomplete recovery to the insurance company; the insurance company should recover only after the insured had been made whole.

A second presumption runs in the opposite direction. This presumption-freedom of contract-stands for the proposition that, left to themselves, parties will find the optimal risk allocation. "Irrationality is usually in the mind of the beholder, not in the mind of the beheld." ${ }^{28}$

It is somewhat surprising, then, that insurance policies so uniformly provide that the insurer take priority, ${ }^{83}$ which means that the insured bears the residual risk of an incomplete recovery from a tortfeasor. The presumptions presented above are not conclusive, however, and there are many reasons why the parties may choose an alternative risk allocation. Any explanation for why the parties would agree to allocate the risk to the insured is also an argument for the pro tanto regime.

${ }^{79}$ A person is risk-averse if he prefers a 100 percent chance of a $\$ 10$ loss to a 10 percent chance of losing $\$ 100$. In other words, he cares "not only about the expected value" of an accident, "but also about the absolute magnitude of the risk." A. Mitchell Polinsky, An Introduction to Law and Economics 53 (Little, Brown 2d ed 1989).

${ }^{80} \mathrm{~A}$ party is risk-neutral if he is indifferent between a 10 percent chance of losing $\$ 100$ and a 100 percent chance of losing $\$ 10$. In other words, he cares only about the potential gain or loss multiplied by the probability of the gain or loss occurring. Id at 29.

${ }^{81}$ See id at 54-55.

${ }^{82}$ Russell L. Ackoff, The Art of Problem Solving 35 (Wiley \& Sons 1978).

${ }^{83}$ See note 4 and accompanying text for examples. 
1. Risk avoidance.

One reason that the parties may choose an alternative scheme of risk allocation is that one party may be in a better position to avoid the risk in the first place. ${ }^{84}$ For example, assume that Shipper and Miller enter into an agreement that Shipper will deliver Miller's broken millshaft to the manufacturer for repairs. ${ }^{85}$ There is a danger that Shipper's ship could break down and delay the repairs. The delay will cost Miller $\$ 100$ and has a 50 percent chance of occurring, but Shipper can exercise care (costing \$5) in maintaining his ship and reduce the chance of delay to 10 percent. Miller can do nothing to reduce the probability of delay. Thus, the expected cost of the delay is $(.1 * 100)=\$ 10$ if Shipper exercises care and $(.5 * 100)=\$ 50$ if he does not. The parties can agree that Miller will pay a premium to Shipper, who will then assume the risk of the delay by agreeing to compensate Miller in the event of a delay. Having assumed the risk, Shipper has an incentive to maintain his ship, and the expected cost of the delay is reduced. As long as Miller pays Shipper between $\$ 5$ and $\$ 10$, both are better off than if Shipper exercises no care and Miller has an expected loss of $\$ 50$.

As between Insurer and Insured, Insured is clearly in a better position to avoid an accident; Insurer can do nothing at all. We might therefore think that the parties would allocate the risk to the Insured, in return for which Insurer would "pay" Insuredin the form of a reduced premium. The difficulty with this argument is that it assumes Insured does not already have sufficient incentives to exercise care and avoid injury. If he does, then there is no reason to allocate more risk to him to induce him to do what he is already doing.

To make this argument convincing, then, one would have to explain why the contributory negligence system does not already provide sufficient incentives to take care. A possible explanation is that the existence of insurance lessens Insured's incentives to exercise care, since he will no longer bear the loss in the event of an injury. This phenomenon is called a moral hazard. ${ }^{86}$

There are two difficulties with this explanation. First, it ignores the fact that Insured already has incentives to take care. If he is injured, he incurs pain and suffering, as well as other damages for which he is not insured. He may also have a deductible 1992).

See Richard A. Posner, Economic Analysis of Law $\$ 4.5$ at 104 (Little, Brown 4th ed

85 The facts are loosely based on Hadley $v$ Baxendale, 156 Eng Rep 145 (Ex 1854).

${ }^{86}$ Polinsky, Introduction to Law and Economics at 56 (cited in note 79). 
or co-insurance, which should eliminate, or at least minimize, the risk of insufficient precautions. ${ }^{87}$ Second, to the extent that Insurer believes that the current deductibles and copayments do not eliminate the moral hazard, it is difficult to see why allocating the risk of incomplete recovery to Insured would be an efficient solution. This risk allocation is a stochastic deductible, imposed at random when the recovery is not complete. If an additional deductible is necessary, it is difficult to understand why it would not be simpler to raise the flat deductible.

\section{Litigation incentives.}

In fact, the risk to be avoided by this allocation is not the accident, but an incomplete recovery from the tortfeasor. Here the incentive argument hits home. A recovery from the tortfeasor depends upon the litigation efforts of both insurer and insured. It makes sense to allocate the risk to the party whose participation is most important to recovering the last dollar. Often the insurer runs the litigation, providing expertise and a legal staff experienced in tort litigation. ${ }^{88}$ The insured is contractually bound to assist with the preparation and presentation of the case. ${ }^{89} \mathrm{But}$ even if an insured is forced to participate, he may not have an incentive to do a good job. If he does not want to testify, he will seek during depositions and on the witness stand to dispose of the case as quickly as possible, rather than making an effort to appear as a sympathetic plaintiff. It therefore makes sense to allocate the risk of an incomplete recovery to him: if he does not do a good job, he will not recover.

At first blush, this argument should apply with equal force to the insurer: by allocating the risk to the insured, the insurer may no longer have a sufficient incentive to prepare the case properly. There is, however, a difference between the insurer and the insured. Unlike the insured, the insurer and its attorneys are repeat players in the insurance and litigation game, and as such would suffer substantial reputational consequences for doing a poor job. If the insurer hires private tort lawyers to present the case and the lawyers do a poor job, they will not be retained in the future. To the extent that the insurer develops a poor track record in winning cases-and therefore recoveries-for its clients, word will get out and its client base will diminish.

\footnotetext{
5ee id at 57.

${ }^{88}$ Telephone interview with Dean Lamb (cited in note 75).

${ }^{89}$ Lamb letter (cited in note 74).
} 


\section{Pure risk aversion.}

Though appealing and intuitive, the foregoing incentive arguments circle wide of the point. The most convincing argument for a pro tanto regime focuses purely and squarely on risk aversion.

One reason that an insured may prefer to bear the risk of an incomplete recovery is that by doing so he ultimately bears less risk. Assume that an insured has a policy with a $\$ 500$ limit and that an accident with a probability of 5 percent will cause $\$ 1,000$ in damages. Assume further that there is a 10 percent probability of a full $\$ 1,000$ recovery from the tortfeasor, a 30 percent probability of a $\$ 500$ recovery, and a 60 percent probability of a $\$ 100$ recovery. This tracks our intuitions that it is easier to recover the first dollar than the last.

When the insurer bears the risk of an incomplete recovery, the premium will be $\$ 22.50 .^{90}$ If, on the other hand, the insured bears the risk of an incomplete recovery, the premium will be only $\$ 13.50$ for the $\$ 500$ policy. ${ }^{91}$ For $\$ 22.50$ he can now purchase a policy with a $\$ 700$ limit. $^{92}$ If he chooses to spend the $\$ 22.50$, he faces a maximum loss of $\$ 266.67$ when he buys $\$ 733.33$ of insurance and bears the risk of an incomplete recovery, as opposed to a maximum loss of $\$ 500$ if he buys the $\$ 500$ of insurance and does not bear the risk of recovery. Recall that a risk-averse person considers not only the expected cost of a loss, but also its absolute magnitude. ${ }^{93}$ Since $\$ 266.67$ is less than $\$ 500$, a truly riskaverse person will choose to spend the same money to buy a larger policy and assume the risk of an incomplete recovery. ${ }^{94}$

${ }^{90} .05[.1(0)+.3(500)+.6(500)]=22.5$. The premiums are set according to the expected cost (probability * magnitude) to the insurer. The insurer only pays out if there is an accident, which happens with a probability of .05 . Even when there is an accident, there is a probability of .1 that the insurer will lose nothing because there will be a full recovery from the tortfeasor. Regardless of the priority regime, all jurisdictions agree that the insurer is entitled to subrogation where the insured is made whole. Next, there is a probability of .3 that there will be a $\$ 500$ recovery from tortfeasor. Under the made-whole regime contemplated by this illustration, the insurer would not recover any of the $\$ 500$ paid out to the insured. Finally, there is a probability of .6 that there will be a $\$ 100$ recovery from the tortfeasor. Again, this will cost the insurer $\$ 500$ since the made-whole doctrine will channel recovery from the tortfeasor to the insured. This model assumes actuarially fair rates, or rates that are set so that the insurance company makes no profit. A richer model, incorporating a profit margin, would be more complicated without changing the result.

91 $.05[.1(0)+.3(0)+.6(400)]=12.0$.

$22.05[.1(0)+.3(\mathrm{x}-400)+.6(\mathrm{x}-100)]=22.5 ; \mathrm{x}=733.33$.

${ }_{93}$ Polinsky, Introduction to Law and Economics at 53 (cited in note 79).

* Nonpecuniary damages such as pain and suffering constitute an important variation on this theme. Pain and suffering insurance is not available, and there is some debate in the academic literature about whether people would purchase the insurance if it 


\section{Strategic Behavior and Transaction Costs}

A court applying the made-whole doctrine to the insurance context must determine whether the insured has been made whole. In this respect, insurance law differs greatly from suretyship. In suretyship subrogation the amount of the loan is fixed, and damages are easy to compute. Therefore, when $A$ loans $B$ $\$ 15,000$ with $\mathrm{C}$ acting as surety, it is clear that once $\mathrm{A}$ has received his $\$ 15,000$, thus having been made whole, subrogation will grant A's right of action against $B$ to $C$. This prevents A from receiving more than his $\$ 15,000$, and places the ultimate burden on B. In insurance subrogation, however, the mechanics are not as straightforward. Even defining the term "made whole" is difficult.

One possible definition is that an accident victim is made whole only when he has received the full compensation he sought from the tortfeasor. But this definition constitutes an open invitation to strategic behavior that could eviscerate subrogation altogether: by seeking an unreasonably large amount of money from the tortfeasor, an insured victim could obtain a double recovery. ${ }^{95}$

Returning to the original example, suppose that $\mathrm{A}$ has been injured in an automobile accident, incurring $\$ 5,000$ of medical expenses for which he is reimbursed by his insurance carrier. He believes that he has also sustained $\$ 10,000$ of pain and suffering. $\mathrm{He}$ also believes that a jury will award him a maximum of $\$ 15,000$ (even if he sues for more). He must now decide how much money to seek from the tortfeasor. Assume he sues the tortfeasor for $\$ 15,000$ - the actual amount of his damages. If he

were. For the argument against insurance for pain and suffering, see generally Alan Schwartz, Proposals for Products Liability Reform: A Theoretical Synthesis, 97 Yale L J 353, 361-67 (1988). But see Steven P. Croley and Jon D. Hanson, The Nonpecuniary Costs of Accidents: Pain-and-Suffering Damages in Tort Law, 108 Harv L Rev 1785 (1995). It is not the purpose of this Comment to rehash these arguments or weigh their merits. Two observations suffice for our purposes. First, to the extent that Professor Schwartz is correct-and people would not purchase insurance against pain and suffering -courts should not apply the made-whole doctrine in cases when pain and suffering account for why the insured has not been made whole, as in the example in the beginning of this Comment. Second, to the extent that some people would prefer to purchase insurance against pain and suffering while others would not, the made-whole doctrine creates crosssubsidization, which should usually be avoided.

${ }^{95}$ Pro rata sharing, while reducing the risk of double recovery, does not eliminate this possibility. Furthermore, under pro rata sharing neither party has as much to gain from pursuing the tortfeasor as it does in either the pro tanto or made-whole regimes. Neither party captures all of the benefits of its efforts, and both may suffer from a collective action problem. If neither brings suit, then the ultimate loss rests on the parties, rather than the tortfeasor, and this may give tortfeasors insufficient incentives to exercise care in avoiding accidents in the first place. 
recovers the full $\$ 15,000$, subrogation will require him to give $\$ 5,000$ to his insurance carrier. If, however, he sues the tortfeasor for a larger amount, such as $\$ 20,000$, and recovers the same $\$ 15,000$, he has not been "made whole" and keeps the full $\$ 15,000$. Since the insurer has already reimbursed him for his medical expenses, he has achieved a double recovery: $\$ 15,000$ for $\$ 10,000$ of remaining damages.

A similar scenario arises if the insured victim believes that a jury will award him any amount more than $\$ 10,000$ but less than $\$ 15,000$. Assume that he believes a jury will award him $\$ 12,000$ (even if he sues for more than $\$ 15,000$ ). When he recovers the $\$ 12,000$, subrogation will require him to give $\$ 2,000$ to his insurance carrier. But if he sues for $\$ 20,000$, claiming $\$ 15,000$ of pain and suffering, then an award of $\$ 12,000$ has not made him whole, and he keeps the full $\$ 12,000$. Since his insurer has reimbursed him for $\$ 5,000$, he has only $\$ 10,000$ of remaining damages; again, he has achieved a double recovery. Therefore, whether an insured has been made whole must not be determined with reference to the amount he has sought from the tortfeasor.

To illustrate this point, consider the following hypothetical (diagramed in Figure 1): Tortfeasor has acted negligently, causing Insured $\$ 10$ pain and suffering damages and $\$ 5$ in medical damages, as in the example above. Insurer reimburses Insured for the medical expenses. A lawsuit costs $\$ 3$, and in the suit against Tortfeasor, Insurer will pay $\$ 1$ and Insured will pay $\$ 2$, in proportion to their expected returns. Insured has a choice of three moves: he may decide not to sue Tortfeasor at all, or he may sue Tortfeasor for either $\$ 15$ or $\$ 20$. Insurer has two choices: participate in the suit and share in the expenses and rewards, or do not participate in the suit. After Insured successfully sues Tortfeasor, ${ }^{96}$ Insurer must decide whether to pursue its subrogation claim against Insured, and Insured must decide whether to defend himself against the suit. Again, a full lawsuit costs each party $\$ 3$, and even if Insured decides not to defend, the process of bringing the suit costs Insurer $\$ 1$.

\footnotetext{
${ }^{9}$ The model assumes that a suit against the tortfeasor will be successful with probability one. While choosing an appropriate probability of success would make the model richer, it would not alter the relative payoffs in any way. Furthermore, the model as developed shows the best-case scenario; by reducing the probability of a successful suit, we only reduce the expected payoff, and provide even less of an incentive for Insurer to press its subrogation claim against Insured.
} 
Insured

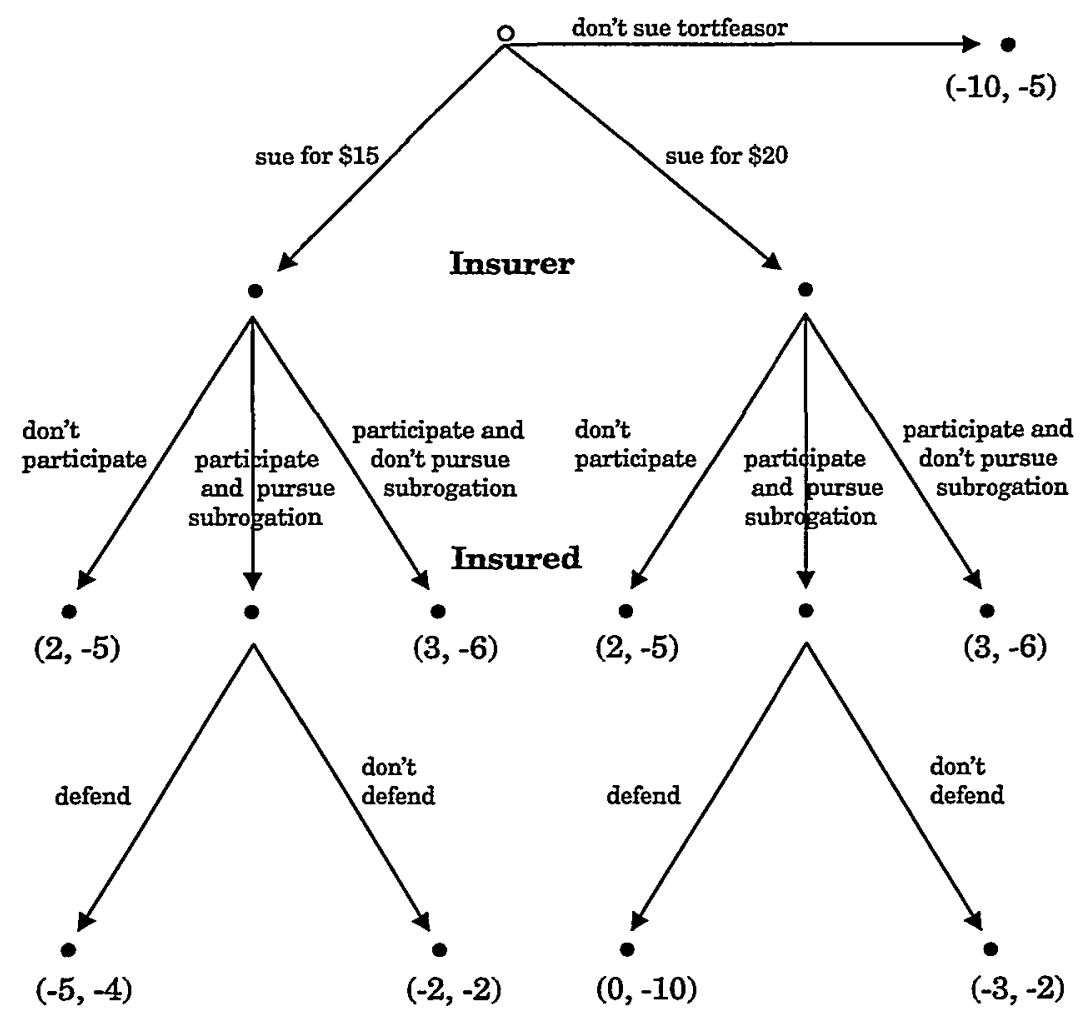

Payoffs: Insured, Insurer

Figure 1

Insured begins the game with $-\$ 15$. The players in this game move sequentially: when Insurer decides whether to pursue its subrogation claim, it knows whether Insured has sued Tortfeasor for $\$ 20, \$ 15$, or not at all. Similarly, when Insured decides whether to defend against Insurer's claim, he knows whether Insurer has decided to pursue its subrogation claim.

Backward induction shows that Insured's dominant strategy $^{97}$ is to sue Tortfeasor for $\$ 20$, and that Insurer's best response is not to participate in Insured's suit against Tortfeasor. Insured is always better off suing than not suing: if he does not sue, he is left with a payoff of $-\$ 10$ (his pain and suffering, since Insurer

${ }^{97}$ A dominant strategy is the strategy "that is a best choice for a player in a game for every possible choice by the other player." Douglas G. Baird, Robert H. Gertner, and Randal C. Picker, Game Theory and the Law 306 (Harvard 1994). 
has reimbursed him for his medical expenses); whereas if he sues his worst payoff is $-\$ 5$.

Insured is worse off suing for $\$ 15$ than suing for $\$ 20$. If Insured sues for $\$ 15$, he has been made whole and must return $\$ 5$ to Insurer. Insurer will know that Insured has sued Tortfeasor for $\$ 15$, and will pursue its subrogation claim, since it is always better off doing so $(-\$ 4>-\$ 6$ and $-\$ 2>-\$ 6)$. Insured will lose if he defends against the subrogation claim, and the defense will still cost him an additional $\$ 3$, leaving him with a net payoff of $-\$ 5$ $(=-\$ 15+\$ 5+\$ 15-\$ 5-\$ 2-\$ 3)$. Insured does better in this subgame by paying Insurer without raising a defense and reaping a net payoff of $-\$ 2(=-\$ 15+\$ 5-\$ 2+\$ 15-\$ 5)$.

On the other hand, if Insured sues for $\$ 20$ and receives $\$ 15$, he has not been made whole. Any attempt by Insurer to pursue its subrogation claim would therefore fail. If Insurer pursues its subrogation claim, Insured's best response is to defend ( $\$ 0>-\$ 2)$. Insurer knows this, and is thus faced with the choice of not pursuing its subrogation claim and a payoff of $-\$ 6$, or pursuing its subrogation claim and a payoff of $-\$ 10(=-\$ 5-\$ 2-\$ 3)$, with no recovery from Insured under this version of the made-whole doctrine. Knowing this, Insurer will choose not to participate in the suit against Tortfeasor in the first place, cutting its losses $\quad(-\$ 5>$ $-\$ 10)$ and leaving Insured to his own devices. ${ }^{98}$ The solution to the game is therefore \{sue for $\$ 20$; don't participate\}, with Insured reaping a recovery of $\$ 3$ in excess of his uncompensated injuries.

This version of the made-whole doctrine thus violates one of the purposes of subrogation: preventing the insured from being unjustly enriched. ${ }^{99}$ We must look elsewhere for a definition of the made-whole doctrine.

In an ideal world, compensation would make an accident victim indifferent between being injured and not being injured. ${ }^{100}$ This suggests another definition for the made-whole doctrine: an accident victim has been made whole when compensation renders him indifferent between not having been injured on the one hand, and having been injured and compensated on the other. While the concept is simple to formulate, the amount that will

\footnotetext{
${ }^{93}$ In the language of game theory, Insurer's strategy of not pursuing its subrogation claim would be termed "strictly dominated." Id at 11.

${ }^{9}$ See text accompanying note 14.

${ }^{100}$ Sullivan v Old Colony Street Railway Co, 197 Mass 512, 83 NE 1091, 1092 (1908) ("The principle on which [the rule of damages] is founded is compensation. Its object is to afford the equivalent in money for the actual loss caused by the wrong of another."). See Posner, Economic Analysis of Law $\$ 6.14$ at 204 (cited in note 84).
} 
achieve precise indifference, neither over- nor undercompensating an accident victim, is likely to exist only as a point in Euclidean space. To paraphrase one court, "No rational man would change places with the injured man for an amount of gold that would fill the room of the court, yet no lawyer would contend that such is the legal measure of damages."101

At least two courts have "solved" the problem by acknowledging the need for a mini-trial on the issue of whether the victim has been made whole. ${ }^{102}$ This solves nothing, and only adds a layer of complexity to an already difficult problem. Without knowing the meaning of "made whole," a factfinder cannot answer the question of whether the insured has been made whole. On this level, a mini-trial constitutes a judicial abdication, requiring a finder of fact to determine whether an undefined requirement has been satisfied.

But the difficulties with this mini-trial have only begun; there are four additional problems. First, determining whether an accident victim has been made whole frequently includes an assessment of nonpecuniary damages such as pain and suffering, requiring a finder of fact to put numbers on the inherently unquantifiable. For example, should the finder of fact measure the victim's damages by how much he would have paid to avoid the injury in the first place, or by how much a tortfeasor would have to pay him to receive permission to commit the tort? ${ }^{103}$

Second, the costs of the mini-trial solution may well run amok. Ignoring the costs of the litigants' time, legal fees alone could easily devour the subrogated amount. At this stage of the litigation, the insured typically has the money paid by the tortfeasor. As the game in Figure 1 suggests, if an insurer finds its expected recovery too low, it will decline to proceed with the mini-trial, leaving the insured with a double recovery, and frustrating the goals of subrogation.

\footnotetext{
${ }^{10}$ Heddles $v$ Chicago \& Northwestern Railway Co, 74 Wis 239, 42 NW 237, 243 (1889).

${ }^{102}$ Rimes, 316 NW2d at 356; Ludwig, 393 NW2d at 146 n 2.

${ }^{103}$ For a discussion of the dizzying complexities of this point, see Mark Geistfeld, Placing a Price on Pain and Suffering: A Method for Helping Juries Determine Tort Damages for Nonmonetary Injuries, $83 \mathrm{Cal}$ L Rev 773 (1995) (concluding that juries, in calculating damages for pain and suffering injuries, should consider how much a reasonable person would have paid ex ante to eliminate the risk of those injuries). See also Edward J. McCaffery, Daniel J. Kahneman, and Matthew L. Spitzer, Framing the Jury: Cognitive Perspectives on Pain and Suffering Awards, 81 Va L Rev 1341 (1995). Courts find calculating damage awards difficult enough as it is. See generally Christopher P. Bowers, Comment, Courts, Contracts, and the Appropriate Discount Rate: A Quick Fix for the Legal Lottery, $63 \mathrm{U}$ Chi L Rev 1099 (1996) (discussing discount rates for lost future profits in contract damage awards).
} 
A third difficulty with a mini-trial is that the insurer is put in the uncomfortable situation of taking inconsistent litigation positions. When the insured victim sues the tortfeasor, it is frequently the insurer who is actually presenting the case. At this point, the insurer must argue that its insured's damages are large and serious, both to obtain a favorable verdict for the insured, and to protect its own subrogation rights. ${ }^{104}$

But in a subsequent mini-trial, the insurer must undertake a forensic reversal of positions: to receive its share of the recovery, the insurer must now argue that the insured has in fact been made whole. To do so, it must argue that the insured would be adequately compensated by a small amount, that his injuries were not so serious after all. Stripped of the legal niceties, the insurer is put in the position of having to say, "fooled you."

Finally, requiring another trial-mini or otherwise-consumes the resources of an already overtaxed judicial system. Courts should seek to simplify the decisionmaking process, not complicate it. Nor is it practical to require the original factfinder to pass on whether the insured has been made whole. First, the determination is no easier than at the earlier stage. Furthermore, in many jurisdictions the collateral source rule hides the insurer's involvement from the jury, giving the insurer no hope of vindicating its rights. ${ }^{105}$ And even without the collateral source rule, the insurer would be placed in the untenable position of arguing, at the same trial, that the damages were both serious and minor. ${ }^{106}$

\section{CONCLUSTON}

The made-whole doctrine rests on tenuous foundations. This Comment has attempted to show that a strict doctrinal approach, based on suretyship doctrine, supports the made-whole doctrine only in two situations: when the statute of limitations has run against the insurer but not against the insured; and when the insured has taken a security interest in an insolvent tortfeasor's property.

\footnotetext{
${ }^{10}$ If the factfinder decides that the insured's injuries are not serious, it may award him little or nothing, and the insured will not have been made whole. Under the madewhole doctrine, the insurer would receive nothing.

${ }^{105}$ See, for example, Mont Code Ann $\S 27-1-308(c)(3)$ (1995); Proctor v Castelletti, 112 Nev 88, 911 P2d 853, 854 (1996).

${ }^{106}$ For a discussion of the complexity and permissibility of taking inconsistent litigating positions, see generally Ashley S. Deeks, Comment, Raising the Cost of Lying: Rethinking Erie for Judicial Estoppel, 64 U Chi L Rev 873 (1997).
} 
Furthermore, the risk allocations in suretyship do not necessarily track those in the insurance context. There is no a priori assumption about the parties' relative risk aversion in suretyship. In contrast, insurers are the quintessential risk spreaders and are therefore entirely risk-neutral. Insureds, by definition, are risk-averse. This difference presents the strongest economic argument for allocating the risk of an incomplete recovery to the insurer.

But even this argument does not stand up to close scrutiny. A risk-averse individual could better protect himself against large losses under a pro tanto regime, by purchasing a policy with a larger limit, than he could under a made-whole regime in which he pays the insurer to assume the risk of an incomplete recovery. Finally, the difficulty of determining when the insured has been made whole, combined with the loss of judicial economy necessitated by a mini-trial, add to the doctrine's inefficiency.

On balance, the pro tanto regime appears to be more efficient for three reasons. First, it better tracks the risk preferences of the parties. Second, it places the incentive to achieve the last dollar of recovery from a tortfeasor on the party whose efforts matter most in achieving it: the insured. Finally, it avoids the definitional problems of the made-whole doctrine and the time and effort of a mini-trial.

This Comment therefore recommends that three steps be taken. First, at a bare minimum, courts should allow subrogation when insurance policies in question provide for it and insurers would be able to proceed under a right of reimbursement rather than subrogation proper. Insurers would do themselves a favor by rewording their policies to allow them recovery under any cause of action-reimbursement, restitution, or subrogation. Second, and preferably, courts should enforce subrogation clauses as they appear in insurance policies, even in situations in which an insurer's statute of limitations has expired or the insured has fortuitously taken a security interest in the tortfeasor's property. This approach is justified by the complications of the made-whole doctrine and the relative risk aversions of the parties. Finally, because of these two factors, both courts and legislatures should adopt pro tanto subrogation as a default rule. 